\title{
FAKTOR YANG BERPENGARUH TERHADAP SIKAP PENERIMAAN MAHASISWA DALAM PENGGUNAAN MEDIA GOOGLE FORM PADA TRY OUT UJI KOMPETENSI
}

\section{FACTORS AFFECTING THE ATTITUDE OF STUDENT ACCEPTANCE IN THE USING OF GOOGLE FORM MEDIA FOR TRY OUT COMPETENCE TEST}

\author{
Anas Tamsuri, ${ }^{* *}$ Suryono ${ }^{2}$ \\ ${ }^{1,2}$ Stikes Pamenang, \\ *Korespondensi Penulis : anastamsuri@ gmail.com, +6281359183826
}

\begin{abstract}
ABSTRAK
Kegiatan Try Out merupakan salah satu upaya penyiapan mahasiswa dalam menghadapi uji kompetensi. Dalam situasi Pandemi akibat Wabah Covid 19 maka bentuk ujian diselenggarakan secara online sesuai dengan kebijakan pemerintah tentang pembatasan sosial. Salah satu metode yang digunakan untuk ujian online adalah dengan media Google Form. Penggunaan media ini merupakan hal baru dan belum pernah diketahui bagaimana penerimaan mahasiswa terhadap media tersebut. Tujuan penelitian ini adalah untuk mengetahui faktor yang berpengaruh terhadap sikap penerimaan mahasiswa dalam penggunaan media Google Form pada Try Out uji kompetensi di Stikes Pamenang Tahun 2020. Desain penelitian adalah cross sectional. Teknik samping yang digunakan adalah simple random sampling dengan jumlah sampel 43 responden. Variabel penelitian ini meliputi variabel dependen yaitu Sikap Penerimaan, variabel independent yaitu tipe perangkat, tipe jaringan dan pengalaman, serta variabel antara (intervening) yaitu persepsi kemudahan dan persepsi kendala. Data diambil dengan kuesioner yang disebarkan melalui Google Form dan dianalisis dengan Regresi Logistis dengan $\alpha=0,05$. Hasil penelitian menunjukkan 16 responden (37\%) tidak setuju dengan penggunaan Google Form. Hasil penelitian juga menunjukkan bahwa variabel tipe perangkat tidak berpengaruh terhadap persepsi kemudahan (Sig. 0,750), tipe jaringan tidak berpengaruh persepsi kemudahan (Sig. 0,650), pengalaman tidak berpengaruh terhadap persepsi kemudahan (Sig. 0567). Variabel tipe perangkat tidak berpengaruh terhadap persepsi kemudahan (Sig. 0,285), tipe jaringan tidak berpengaruh terhadap persepsi kemudahan (Sig. 0,847), sedangkan pengalaman berpengaruh terhadap persepsi kendala (Sig. $0,016)$ dengan odd ratio 5,22. Penelitian ini juga mendapati bahwa faktor persepsi kemudahan tidak berpengaruh terhadap sikap penerimaan penggunaan Google Form sebagai media ujian Try Out (Sig. 0,489), dan begitu juga didapaktan bahwa persepsi kendala tidak berpengaruh terhadap sikap penerimaan penggunaan Google Form sebagai media ujian Try Out (Sig. 0,976). Dari hasil penelitian maka disarankan dikembangkan penelitian lebih lanjut tentang faktor lain yang berpengaruh terhadap penerimaan penggunaan Google Form sebagai metode test.
\end{abstract}

Kata kunci: Try Out, Google Form, Uji Kompetensi

\begin{abstract}
Try Out activity is an effort to prepare students in facing the competency test. In a Pandemic situation due to the Covid 19 Outbreak, the form of exams was held online in accordance with government policy on social distancing. One method used for online exams is the Google Form media. The use of this media is new and it has never been known how the acceptance of students towards the media. The purpose of this study is to determine the factors that influence the attitude of acceptance of students in the use of Google Form media on the Try Out competency test at Pamenang School of Health in 2020. The study design was cross sectional. The sampling technique used was simple random sampling with sample size of 43 respondents. The variables of this study included the dependent variable: Attitide of Acceptance toward Google Form using as media of Try Out and the independent variable included : the type of device, the type of network, and experience; and the intervening variable, namely the perception of ease and perception of constraints. Data was collected using a questionnaire distributed via Google Form and analyzed
\end{abstract}


with Logistic Regression with $\alpha=0.05$. The results showed 16 respondents (37\%) did not agree with the use of Google Form. The results also showed that the type of device did not affect the perception of convenience (Sig. 0.750), the type of network did not affect the perception of ease (Sig. 0.650), experience did not affect the perception of ease (Sig. 0567). The type of device variable did not affect the perception of convenience (Sig. 0.285), the type of network did not affect the perception of ease (Sig. 0.847), while experience affect the perception of constraints (Sig. 0.016) with an odd ratio of 5.22. This study also found that the perceived ease factor did not affect the attitude of accepting the use of Google Form as a Try Out test media (Sig. 0.489), and likewise it was found that the perception of constraints had no effect on the attitude of accepting the use of Google Form as a Try Out test media (Sig. .976). From the results of the study it is recommended that further research be developed about other factors that influence the acceptance of using Google Form as a test method.

Keywords: Tryout, Google form, Competence test

\section{PENDAHULUAN}

Perawat adalah salah satu tenaga pelayanan kesehatan yang hampir terdapat pada setiap tatanan pelayanan kesehatan di Indonesia dan menempati tenaga dengan kebutuhan terbanyak. Keberadaan tenaga perawat diharapkan mampu memberikan kontribusi yang positif bagi penurunan angka morbiditas, mortalitas dan disabilitas serta mampu mengembangkan gaya hidup sehat pada masyarakat (Masfuri, 2016). Pun demikian hal ini belum tentu dapat dicapai manakala kondisi lingkungan pekerjaan yang kurang sesuai maupun karena kompetensi yang dimiliki kurang relevan atau tidak dapat memenuhi standart yang diharapkan (Masfuri, 2016; WHO, 2003). Berdasarkan pada situasi diatas maka mulai tahun 2013 pemerintah mengembangkan penjaminan mutu melalui penyelenggaraan uji kompetensi bagi lulusan pendidikan tinggi keperawatan (Iriana, 2019). Uji Kompetensi adalah proses pengukuran pengetahuan, keterampilan, dan perilaku peserta didik pada perguruan tinggi yang menyelenggarakan pendidikan tinggi bidang kesehatan; termasuk didalamnya adalah perawat (jdih.kemdikbud.go.id, 2020). Namun demikian ternyata tingkat kelulusan peserta (perawat) pada ujian kompetensi masih relatif rendah.

Data menunjukkan bahwa pada tahun 2013 tingkat kelulusan secara nasional hanya sebesar 67,91 \%. Pada tahun 2014, dari 29.984 peserta uji kompetensi, yang lulus uji kompetensi hanya sebanyak 50,71 \%; dan pada pelaksanaan uji kompetensi pada periode tahun 2015; dari 33.868 peserta, yang dinyatakan lulus uji kompetensi adalah sebanyak 64,38 \% (Iriana, 2015). Adapun angka kelulusan uji kompetensi nasional pada periode Oktober 2016 sebesar 48\%, pada periode Oktober 2017 sebesar 82,13\% serta angka kelulusan periode Oktober 2018 sebesar 86,02\% (Yitno, 2019). Sedangkan kelulusan uji kompetensi nasional periode Juli 2019 didapatkan sebesar 68,46\% (Ghofar, 2019)

Di Jawa Timur sendiri angka kelulusan peserta ujian kompetensi pada periode November 2014 didapatkan angka kelulusan sebesar 68,2\%, pada periode September 2015 diperoleh angka kelulusan 82,30 \%, pada periode Oktober 2016 didapatkan angka kelulusan $72,60 \%$, pada periode ujian Oktober 2017 diperoleh angka kelulusan 94,30 \% dan pada periode Oktober tahun 2018 diperoleh angka kelulusan 86,02 \% (Yitno, 2019). Sedangkan pada uji kompetensi periode Agustus 2019 didapatkan sebesar 68,46\% (Ghofat,2019). Data menunjukkan bahwa prosentase kelulusan di Jawa Timur relatif lebih baik dibandingkan dengan data nasional, namun tetap saja menyisakan masalah karena masih terdapat lulusan yang belum dapat menyelesaikan uji kompetensi (Ghofar, 2016). Secara sosial, tingginya angka kelulusan uji kompetensi memberikan dampak yang signifikan. Sebagaimana dipahami bahwa mahasiswa yang telah lulus semestinya dapat mempergunakan ijazahnya untuk bekerja, namun karena mereka belum lulus uji kompetensi sebagai persyaratan untuk mendapatkan Surat Tanda Registrasi (STR) maka menyebabkan kesempatan untuk bekerja menjadi terhambat.

Salah satu aspek penting dalam proses pendidikan untuk menyiapkan mahasiswa perawat agar mampu menghadapi uji 
kompetensi dengan baik adalah dengan menyelenggarakan kegiatan Try Out uji kompetensi. Kegiatan Try Out merupakan salah satu upaya penyiapan mahasiswa dalam menghadapi uji kompetensi yang dapat diselenggarakan oleh perguruan tinggi sebagai bagian dari proses baik (Good practice) untuk menyiapkan mahasiswa (Iriana, 2019). Beberapa penelitian menunjukkan bahwa Try Out memiliki pengaruh terhadap kelulusan uji kompetensi. Penelitian dari Hartina, dkk (2017) yang dilakukan pada mahasiswa pogram studi ners menunjukkan bahwa peserta yang mengikuti Try Out uji kompetensi memiliki peluang lebih besar dibandingkan mereka yang tidak mengikuti Try Out. Stikes Pamenang selama beberapa tahun telah menyelenggarakan ujian akhir program yang sekaligus sebagai bentuk Try Out uji kompetensi untuk menyiapkan mahasiswa/ lulusan menghadapi uji kompetensi. Selama ini ujian Try Out dilakukan dengan pendekatan paper base (berbasis kertas) dimana peserta hadir di ruang ujian dan mengerjakan soal yang diberikan. Pada tahun 2020, penyelenggaraan ujian berbeda karena situasi wabah Covid 19 yang melanda Indonesia dan Dunia. Mengacu pada edaran dari Lembaga Layanan Dikti wilayah VII nomor 578 tahun 2020 tertanggal 16 Maret 2020 tentang Pencegahan Corona Virus Disease (Covid 19) pada Perguruan Tinggi di Lingkungan LLDIkti Wilayah VII maka proses penyelenggaraan pendidikan dalam bentuk tatap muka langsug digantikan dengan metoda daring. Salah satu aspek yang juga digantikan adalah metoda evaluasi dan Try Out ujian kompetensi. Metode Try Out uji kompetensi yang diselenggarakan selama ini menggunakan metode kertas diganti dengan menggunakan metode online menggunakan Google Form. Aplikasi ujian online adalah aplikasi yang bertujuan mempermudah melakukan ujian, yaitu secara online. Aplikasi ujian online tersebut menjadi sarana bagi pengguna untuk ujian dengan tidak dibatasi oleh ruang karena dapat dilakukan dan diakses di mana saja selama terdapat akses internet. Penggunaan Google Form sebagai media ujian karena merupakan salah satu software yang mudah diakses, gratis dan bebas digunakan, mudah dioperasikan serta cukup baik untuk dikembangkan sebagai alat evaluasi (Budie Agung, dkk, 2018). Google Form dalam kepentingan ujian/test dapat diwujudkan dalam soal pilihan ganda (Kim \& Park; 2012). Karena penggunaan Google Form sebagai media ujian try out uji kompetensi baru pertama kali dilakukan dan belum ada laporan penelitian sebelumnya tentang hal tersebut, maka perlu digali lebih lanjut bagaimana penerimaan mahasiswa terhadap Google Form sebagai media Try Out uji kompetensi dan termasuk faktor yang mempengaruhinya.

Tujuan umum dari penelitian ini adalah untuk mengetahui faktor yang berpengaruh terhadap sikap penerimaan mahasiswa dalam penggunaan media Google Form pada Try Out uji kompetensi di Stikes Pamenang Tahun 2020.

Sedangkan tujuan khusus dari penelitian ini antara lain:

1. Menganalisis pengaruh tipe perangkat, tipe jaringan dan pengalaman terhadap persepsi kemudahan dalam penggunaan media Google Form pada Try Out Uji Kompetensi

2. Menganalisis pengaruh tipe perangkat, tipe jaringan dan pengalaman terhadap persepsi kendala dalam penggunaan media Google Form pada Try Out Uji Kompetensi

3. Menganalisis pengaruh persepsi kemudahan dan persepsi kendala terhadap sikap penerimaan mahasiswa dalam penggunaan media Google Form pada Try Out uji kompetensi

\section{METODE}

Penelitian ini merupakan jenis penelitian kualitatif dengan pendekatan cross sectional, yaitu data variabel dependen dan variabel dependent diambil dalam satu waktu pengambilan data. Populasi penelitian ini adalah mahasiswa program D-3 Keperawatan Stikes Pamenang sejumlah 47 mahasiswa. Adapun sampel penelitian ini adalah 43 mahasiswa, dengan teknik pengambilan sampling : simple random sampling. Pengumpulan data dilakukan beberapa jam setelah pelaksanaan ujian, yaitu pada tanggal 1 Mei 2020 menggunakan kuesioner yang disusun sendiri oleh peneliti, dan disebarkan menggunakan Google Form untuk diisi.

Variabel penelitian ini meliputi variabel dependen yaitu sikap penerimaan terhadap Try Out, dan variabel independen meliputi tipe perangkat, tipe jaringan dan pengalaman. Selain itu terdapat variabel antara yaitu variabel persepsi kemudahan dan variabel persepsi kendala. 
Variabel dependen : Sikap penerimaan terhadap try out adalah kecenderungan untuk memilih berdasarkan penilaian subyektif individu terhadap penyelenggaraan try out menggunakan aplikasi Google Form pada periode berikutnya. Variabel ini diukur dengan kuesioner melalui google form dalam skala nominal (setuju/ tidak setuju).

Variabel independen tipe perangkat adalah jenis alat elektronik yang digunakan oleh responden ketika mengakses google form. Variabel ini diukur dengan kuesioner melalui Google form dalam skala nominal. Variabel tipe jaringan adalah sumber jaringan internet yang digunakan untuk mengakses soal saat ujian. Variabel ini diukur dengan kuesioner melalui google form dalam skala nominal. Variabel pengalaman adalah pernyataan subyektif responden tentang pengalamannya menggunakan Google form untuk ujian sebelumnya. Variabel ini diukur dengan kuesioner melalui google form dengan skala nominal (pernah/ tidak pernah). Variabel persepsi kemudahan adalah penilaian individu secara personal terhadap seberapa mudah atau sulit mereka mengoperasikan google form ketika mengerjakan ujian. Variabel ini diukur dengan kuesioner dengan skala data nominal. Variabel persepsi kendala adalah penilaian individu secara personal terhadap seberapa besar kendala yang mereka hadapi ketika mereka mengoperasikan google form saat mengerjakan ujian. Variabel ini dinilai dengan kuesioner dalam skala nominal.

Pengolahan dan penyajian data dilakukan secara deskriptif dengan menggunakan Microsoft Excel, dan dilanjutkan dengan tahapan analisis data dengan menggunakan uji regresi logistik dengan software SPSS pada $\alpha=0.05$. Besar koefisien regresi ditentukan dari persamaan yang didapatkan dari model matematis yang terbentuk atas hubungan antar variabel.

HASIL

1. Pengalaman Responden Menggunakan Google Form

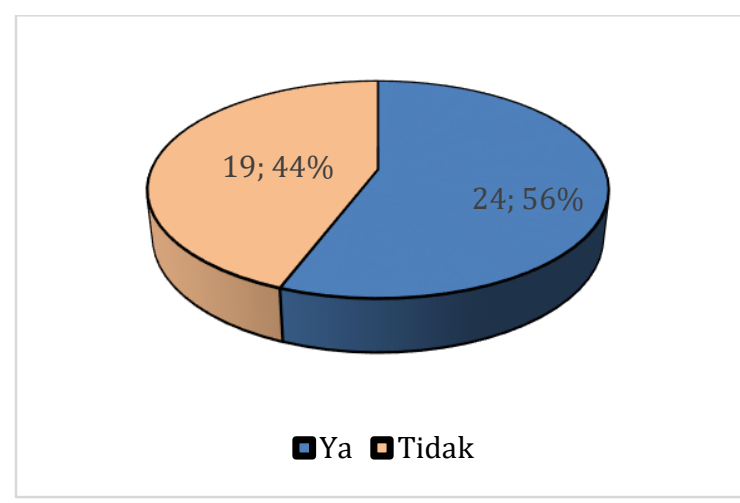

Diagram 1. Pengalaman penggunaan Google Form untuk test

Dari diagram diatas didapatkan 24 responden $(56 \%)$ memiliki pengalaman menggunakan Google Form untuk test/ ujian, sedangkan 19 responden (44\%) tidak memiliki pengalaman menggunakan Google Form untuk ujian.

\section{Tipe Perangkat Dalam Ujian}

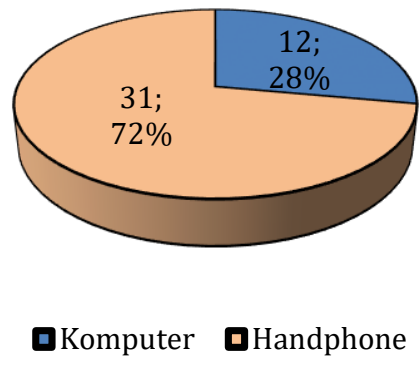

Diagram 2. Tipe perangkat untuk mengakses Google Form

Dari hasil penelitian didapatkan 31 mahasiswa (72\%) menggunakan Handphone untuk mengakses soal ujian Try Out

3. Tipe jaringan internet dalam ujian

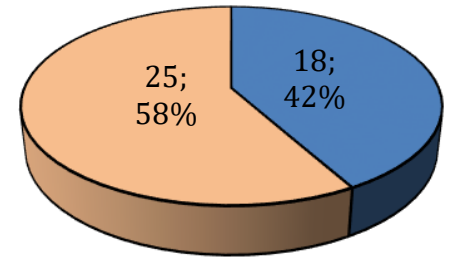

口WiFi Daket Data

Diagram 3. Tipe jaringan internet untuk mengakses Google Form 
Hasil penelitian menunjukkan 25 responden (58\%) mengakses ujian dengan menggunakan paket data seluler dari handphone.

\section{Persepsi Kemudahan Pengerjaan Soal}

Persepsi kemudahan pengerjaan soal diukur dari berbagai aspek antara lain dari persepsi tentang kemudahan membaca soal, kemudahan navigasi (berpindah dari satu bagian soal ke bagian yang lain), persepsi kemudahan melakukan pengecekan soal yang belum dikerjakan, kemudahan mengisi jawaban dan sebagainya. Data selanjutnya transformasi menjadi data kategori sebagai (dengan cut point nilai 20) sehingga kategori data menjadi sebagai berikut:

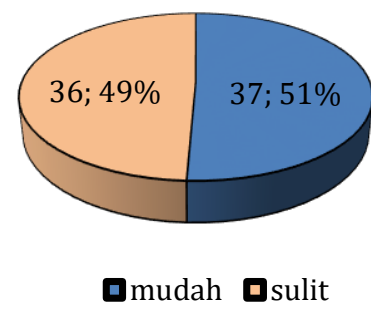

Diagram 4. Persepsi kemudahan pengerjaan soal dengan Google Form

Hasil penelitian menunjukkan 37 responden $(51 \%)$ mengalami kesulitan dalam mengoperasikan google form saat pelaksanaan ujian.

\section{Persepsi Kendala Dalam Pengerjaan Soal}

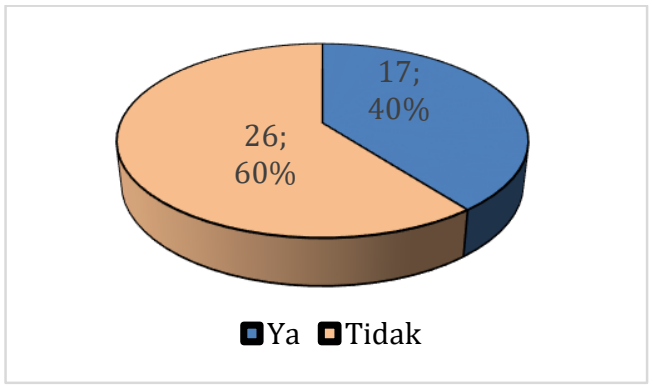

Diagram 5. Persepsi kendala dalam pengerjaan ujian Try Out dengan Google Form

Dari hasil penelitian didapatkan terdapat 17 responden (40\%) dengan masalah / kendala dan 26 responden $(60 \%)$ tidak mengalami kendala.
6. Sikap Penerimaan Responden Terhadap Pelaksanaan Ujian Dengan Google Form

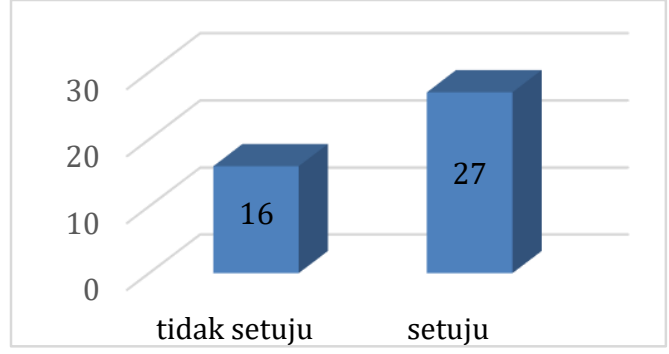

Diagram 6. Sikap penerimaan responden terhadap penggunaan Google Form untuk Try Out uji kompetensi

Dari hasil penelitian didapatkan terdapat $16(37 \%)$ responden yang tidak setuju dengan penggunaan Google Form untuk ujian Try Out dan $27(63 \%)$ responden menyatakan setuju penggunaan Google Form untuk ujian Try Out

7. Pengaruh Tipe Perangkat, Tipe Jaringan Dan Pengalaman Terhadap Persepsi Kemudahan Dalam Penggunaan Media Google Form Pada Try Out Uji Kompetensi

Beberapa variabel yang secara logis berhubungan dengan persepsi kemudahan penggunaan Google Form untuk ujian antara lain adalah pengalaman, jenis perangkat yang digunakan serta jaringan internet.

Hasil uji regresi dengan regresi ordinal sederhana (satu variabel independent) dengan melakukan entri variabel satu per satu didapatkan hasil sebagai berikut :

Tabel 1. Nilai Exp (B) dan Signifikansi Pengaruh Variabel Independen terhadap variabel Persepsi kemudahan

\begin{tabular}{|l|l|l|}
\hline Variabel & $\begin{array}{l}\text { Nilai Exp } \\
(\mathrm{B})\end{array}$ & Sign. \\
\hline Tipe Perangkat & 0.741 & 0.750 \\
\hline Tipe Jaringan & 1.524 & 0.650 \\
\hline Pengalaman & 0.588 & 0.567 \\
\hline
\end{tabular}

Dari hasil pengujian secara parsial didapatkan sebagaimana tabel diatas didapatkan bahwa tidak ada variabel yang diteliti yang mampu menjadi kandidat sebagai prediktor kemudahan menggunakan Google Form untuk ujian Try Out Uji Kompetensi. 
8. Pengaruh tipe perangkat, tipe jaringan dan pengalaman terhadap persepsi kendala dalam penggunaan Media Google Form pada Try Out Uji Kompetensi

Beberapa variabel yang secara logis berhubungan dengan persepsi kendala dalam penggunaan Google Form untuk ujian antara lain adalah pengalaman, jenis perangkat yang digunakan serta jaringan internet.

Hasil uji regresi dengan regresi ordinal sederhana (satu variabel independent) dengan melakukan entri variabel satu per satu didapatkan hasil sebagai berikut :

Tabel 2. Nilai Exp (B) dan Signifikansi Pengaruh Variabel Independen terhadap variabel Persepsi Kendala

\begin{tabular}{|l|l|l|}
\hline Variabel & $\begin{array}{l}\text { Nilai Exp } \\
(\mathrm{B})\end{array}$ & Sign. \\
\hline Tipe Perangkat & 0.476 & 0.285 \\
\hline Tipe Jaringan & 0.131 & 0.847 \\
\hline Pengalaman & 5.205 & 0.016 \\
\hline
\end{tabular}

Dari hasil pengujian secara parsial didapatkan bahwa variabel yang mampu menjadi kandidat sebagai prediktor kendala pengerjaan ujian tryout dengan Google Form adalah pengalaman.

Hasil pengujian lebih lanjut didapatkan hasil sebagai berikut:

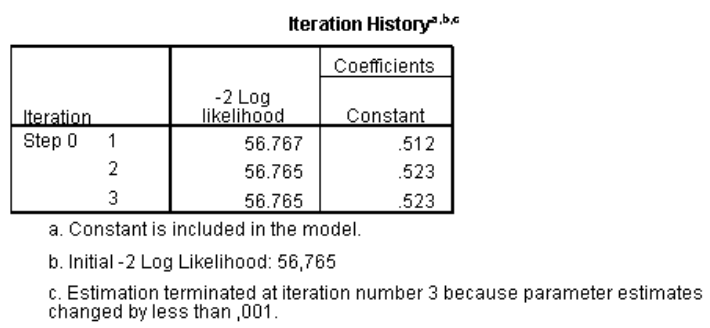

Hasil uji pada tabel iteration history pada blok 0 (saat variabel independen tidak dimasukkan dalam model didapatkan nilai -2 $\log$ Likelihood 56,765. Nilai ini lebih kecil dari Chi kuadrat tabel untuk df 42 yaitu 58,124 , yang bermakna bahwa sebelum variabel independen dimasukkan model sebenarnya telah fit dengan data.

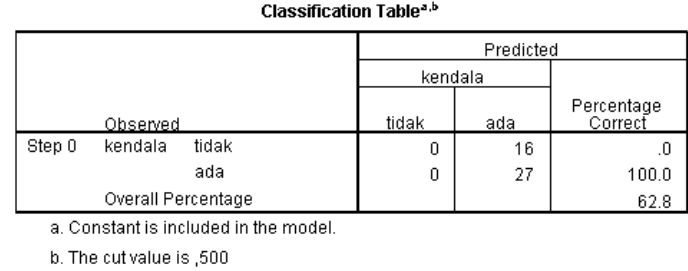

Dari tabel klasifikasi diperoleh nilai persentase 63,8; artinya bahwa overall persentage sebelum variabel independen dimasukkan kedalam model sebesar 27/43 yatu $62,8 \%$.

Variables in the Equation
\begin{tabular}{|l|r|}
\hline & Step 0 \\
\cline { 2 - 2 } & Constant \\
\hline B & .523 \\
S.E. & .315 \\
Wald & 2.751 \\
df & 1 \\
Sig. & .097 \\
Exp(B) & 1.687 \\
\hline
\end{tabular}

Sebelum variabel independen dimasukan kedalam model, nilai slope atau koefisien beta (B) dari konstanta adalah sebesar 0,538 dengan Odd ratio atau $\operatorname{Exp}(\mathrm{B})$ sebesar 1.687. Nilai signifikansi atau $\mathrm{p}$ value dari uji Wald sebesar 0,097

Adapun hasil saat variabel dimasukkan kedalam persamaan maka diperoleh hasil sebagai berikut :



Nilai -2 log Likelihood 50,427. Nilai ini lebih kecil dari Chi kuadrat tabel untuk df 42 yaitu 58,124, yang bermakna bahwa sebelum variabel independen dimasukkan model telah fit dengan data.

Omnibus Tests of Model Coefficients
\begin{tabular}{|ll|r|r|r|}
\hline & & Chi-square & \multicolumn{1}{c|}{ df } & \multicolumn{1}{c|}{ Sig. } \\
\hline Step 1 & Step & 6.338 & 1 & .012 \\
& Block & 6.338 & 1 & .012 \\
& Model & 6.338 & 1 & .012 \\
\hline
\end{tabular}


Nilai Omnibus Test menunjukkan nilai Chi kuadrat 6,338. Nilai ini lebih besar dari Xhi kuadrat tabel untuk degree of freedom 1 (jumlah variabel 1) yaitu 3,841; atau dengan signifikansi sebesar 0,012 lebih kecil dari 0,05 yang artinya bahwa variabel independen dapat memberikan pengaruh nyata terhadap model, atau dengan kata lain model dinyatakan fit.

\begin{tabular}{|l|c|c|c|}
\multicolumn{3}{c}{ Model Summary } \\
\hline Sten & $\begin{array}{c}-2 \mathrm{Log} \\
\text { likelihood }\end{array}$ & $\begin{array}{c}\text { Cox \& Snell R } \\
\text { Square }\end{array}$ & $\begin{array}{c}\text { Nagelkerke R } \\
\text { Square }\end{array}$ \\
\hline 1 & $50.427^{\mathrm{a}}$ & .137 & .187 \\
\hline
\end{tabular}

Nilai Cox \& Snell R Square serta Nagelkerke R Square digunakan utuk melihat kemampuan variabel independen dalam menjelaskan variabel dependen. Nilai Nagelkerke R Suare sebesar 0, 187 artinya bahwa kemampuan variabel independen dalam menjelaskan variabel dependen sebesar $18,7 \%$ sedangkan sisanya $(81,3 \%)$ dijelaskan oleh faktor lain diluar model.

Hosmer and Lemeshow Test
\begin{tabular}{|l|r|r|r|}
\hline Sten & Chi-square & df & Sig. \\
\hline 1 & .000 & 0 &. \\
\hline
\end{tabular}

Hasil pengujian dengan Hosmer \& Lemeshow test sebagai uji Goodness of Fit test menunjukkan nilai Chi Square 0,00. Nilai ini tidak dapat direview karena nilai Chi Square atas degree of freedom 0 (jumlah variabel -1) tidak dapat ditentukan.

\begin{tabular}{|c|c|c|c|}
\hline \multicolumn{4}{|c|}{ Variables in the Equation } \\
\hline & & \multicolumn{2}{|c|}{ Step 1} \\
\hline & & $\begin{array}{c}\text { pengalaman } \\
\text { (1) }\end{array}$ & Constant \\
\hline$B$ & & 1.653 & -.318 \\
\hline S.E. & & .685 & .465 \\
\hline Wald & & 5.835 & .470 \\
\hline$d f$ & & 1 & 1 \\
\hline Sig. & & .016 & .493 \\
\hline $\operatorname{Exp}(B)$ & & 5.225 & .727 \\
\hline $95,0 \%$ C.I.for $\operatorname{EXP}(\mathrm{B})$ & Lower & 1.366 & \\
\hline & Upper & 19.986 & \\
\hline
\end{tabular}

Besaran pengaruh variabel independen terhadap variabel dependen ditentukan berdasarkan nilai Odd ratio (OR) atau nilai $\operatorname{Exp}(\mathrm{B})$ yaitu sebesar 5,225. Nilai dari odd rasio adalah positif, artinya seseorang yang berpengalaman akan cenderung tidak mengalami kendala penggunaan Google Form 5,2 kali lebih besar.
9. Pengaruh Persepsi Kemudahan Dan Persepsi Kendala Terhadap Sikap Penerimaan Mahasiswa Dalam Penggunaan Media Google Form Pada Try Out Uji Kompetensi

Penelitian menunjukkan bahwa dari pengalaman menjalankan Try Out uji kompetensi dengan menggunakan Google Form, didapatkan terdapat $16 \quad(37 \%)$ responden yang tidak setuju dengan penggunaan Google Form untuk ujian Try Out dan 27 (63\%) responden menyatakan setuju penggunaan Google Form untuk ujian Try out Hasil uji regresi dengan regresi nominal (satu variabel independent) dengan melakukan entri variabel satu per satu didapatkan hasil sebagai berikut :

Tabel 3. Nilai Exp (B) dan Signifikansi Pengaruh Variabel Independen terhadap variabel dependen

\begin{tabular}{|l|l|l|}
\hline Variabel & $\begin{array}{l}\text { Nilai Exp } \\
\text { (B) }\end{array}$ & Sign. \\
\hline Kendala & 0.980 & 0.976 \\
\hline Kemudahan & 0.582 & 0.489 \\
\hline
\end{tabular}

Dari hasil pengujian secara parsial didapatkan bahwa variabel yang diteliti tidak ada yang mampu menjadi kandidat sebagai prediktor sikap responden/ peserta dalam pengerjaan ujian tryout dengan Google Form.

\section{PEMBAHASAN}

1. Pengaruh Tipe Perangkat, Tipe Jaringan dan Pengalaman Terhadap Persepsi Kemudahan Dalam Penggunaan Google Form pada Try Out Uji Kompetensi

Hasil penelitian menunjukkan bahwa jenis perangkat yang digunakan untuk ujian (komputer/ laptop) maupun penggunaan handphone tidak memberikan pengaruh terhadap persepsi kemudahan (Sig. 0,750). Jaringan yang digunakan (jaringan data seluluar maupun jaringan Wi-Fi Internet) tidak berpengaruh terhadap persepsi kemudahan (Sig. 0,650) serta pengalaman mengerjakan test online sebelumnya ternyata tidak memberikan pengaruh terhadap persepsi kemudahan (Sig. 0,567)

Try Out merupakan suatu mekanisme yang digunakan oleh seseorang sebagai 
sebuah latihan sebelum ia melaksanakan ujian yang sesungguhnya.

Google Form merupakan media dapat digunakan oleh semua orang secara bebas dengan menggunakan laptop atau smartphone yang terhubung dengan internet (M. Khairudin, F. Wulandari, D Mardapi, 2020). Walaupun awalnya pengunaan Google Form untuk kegiatan survey atau penelitan, beberapa penelitian menunjukkan variasi penggunaan Google Form antara lain seperti untuk kegiatan registrasi (Raharja, Lutfiani \& Alfansuri, 2018), kegiatan pengumpulan data medik (Rakib U. Rayhan, et.al.,2013), kegiatan pembelajaran (Kim\&Park, 2012) dan untuk test (M.Iqbal, dkk, 2018). Penggunaan Google Form sangat tergantung pada jaringan internet yang menjadi platform aplikasi ini, dan karenanya mudah atau tidaknya penggunaan Google Form sangat dipengaruhi oleh kualitas jaringan internet yang digunakan untuk mengakses media saat pelaksanaan ujian; dan bukan oleh jenis perangkat dan jenis jaringan yang digunakan untuk mengakses Google Form pada ujian online.

Pada sisi lain, Google Form merupakan aplikasi yang mudah digunakan/mudah dioperasikan (Budie Agung, dkk, 2018) dan karenanya bagi peserta ujian online walaupun belum pernah menggunakannya tetap akan merasa mudah untuk menggunakan dalam ujian. Berdasarkan pada hal itu maka dimungkinkan persepsi pengguna yang sebelumnya tidak memiliki pengalaman test dengan menggunakan Google Form tidak semuanya mempersepsikan bahwa pelaksanaan ujian relatif sulit.

2. Pengaruh Tipe Perangkat, Tipe Jaringan Dan Pengalaman Terhadap Persepsi Kendala Dalam Penggunaan Google Form Pada Try Out Uji Kompetensi

Hasil penelitian menunjukkan bahwa jenis perangkat yang digunakan untuk ujian (komputer/laptop) maupun penggunaan Handphone tidak memberikan pengaruh terhadap persepsi kendala (Sig. 0,285). Jaringan yang digunakan (jaringan data seluluar maupun jaringan Wi-Fi Internet) tidak berpengaruh terhadap persepsi kendala (Sig. 0,847) serta pengalaman mengerjakan test online sebelumnya memberikan pengaruh terhadap persepsi kendala (Sig. 0,016)
Dari hasil pengujian secara parsial didapatkan bahwa variabel yang mampu menjadi kandidat sebagai prediktor kendala pengerjaan ujian tryout dengan Google Form adalah pengalaman.

Lebih lanjut didapatkan nilai Odd Ratio (OR) atau nilai $\operatorname{Exp}(\mathrm{B})$ yaitu sebesar 5,225 yang artinya seseorang yang berpengalaman akan cenderung tidak mengalami kendala penggunaan Google Form 5,2 kali lebih besar dibandingkan yang tidak memiliki pengalaman.

Try Out menjadi media untuk berlatih mengerjakan soal. Semakin sering berlatih, peserta didik akan semakin siap untuk menghadapinya karena kesuksesan itu dimulai dari banyaknya latihan atau persiapan yang matang (Hartina, Ayu; dkk, 2017). Melalui penyelenggaraan Try Out diharapkan mahasiswa dapat mengenal model soal maupun mengenal teknis ujian yang diselenggarakan (Iriana, 2019). Penyelenggaraan Try Out penting untuk dibuat sistem yang membuat mahasiswa/peserta merasakan nuansa ujian sehingga secara teknis maupun psikologis mereka lebih siap menghadapi ujian yang sesungguhnya.

Mengacu pada karakteristik dari Google Form bahwa ia merupakan media yang terhubung dengan internet (M. Khairudin, F. Wulandari, D Mardapi, 2020), maka penggunaan Google Form sangat tergantung pada kualitas jaringan internet yang menjadi platform aplikasi ini, dan bukan karena perangkat maupun jalur akses.

pendapat Budi Agung, dkk (2018) bahwa Google Form merupakan aplikasi yang mudah digunakan/mudah dioperasikan, maka semestinya tidak banyak kendala yang terjadi pada penggunaan aplikasi ini yang terkait dengan perangkat maupun teknis operasional penggunaan aplikasi. Pun demikian, hasil penelitian menunjukkan bahwa $40 \%$ responden menyatakan adanya kendala dalam penggunaan Google Form untuk pelaksanaan Try Out. Kendala ini ternyata terkait dengan masalah jaringan. Hal ini relevan denga hasil penelitian dari Budie Agung, dkk (2018) dimana responden terdapat kesulitan melakukan test dengan Google Form, namun mereka tetap menganggap positif dan setuju dengan penggunaan Google Form untuk ujian karena kendala yang dihadapai bukan pada kesulitan mengoperasikan Google Form, 
namun karena terbatasnya kuota internet atau gangguan jaringan internet.

\section{Pengaruh Persepsi Kemudahan Dan} Persepsi Kendala Terhadap Sikap Penerimaan Mahasiswa Dalam Penggunaan Media Google Form Pada Try Out Uji Kompetensi

Dari hasil penelitian didapatkan bahwa 16 responden (37\%) tidak setuju dengan penggunaan Google Form untuk ujian Try out pengujian secara parsial juga didapatkan variabel yang diteliti tidak ada yang mampu menjadi kandidat sebagai prediktor sikap responden/peserta dalam pengerjaan ujian try out dengan Google Form. Hasil penelitian menunjukkan bahwa persepsi kemudahan tidak pengaruh terhadap sikap penerimaan (Sig. 0,489), dan persepsi kendala tidak pengaruh terhadap sikap penerimaan (Sig. 0,976).

Memperhatian karakteristik dari Google Form yang mudah untuk digunakan dan merupakan aplikasi berbasis internet (M. Khairudin, F. Wulandari, D Mardapi, 2020), maka dapat dipahami bahwa penolakan atau penerimaan penggunaan Google Form ini bukan terkait dengan kesulitan penggunaan atau terkait persepsi kemudahan, namun karena faktor lain yaitu faktor kualitas jaringan internet.

Hal ini sesuai dengan penelitian dari Budie Agung, dkk (2018) dimana responden terdapat kesulitan melakukan test dengan Google Form karena terkait dengan keterbatasan kuota internet (data internet) ataupun karena jaringan internet yang kurang mendukung pelaksanaan ujian.

\section{KESIMPULAN DAN SARAN Kesimpulan}

Berdasarkan penelitian didapatkan bahwa jenis perangkat, pengalaman dan jenis akses internet tidak berpengaruh terhadap persepsi kemudahan penggunaan Google Form untuk ujian Try Out uji kompetensi; dan pengalaman berpengaruh terhadap kendala penggunaan Google Form untuk ujian Try Out uji kompetensi. Hasil penelitian juga menunjukkan bahwa persepsi kemudahan dan persepsi kendala tidak berpengaruh terhadap rekomendasi penggunaan Google Form untuk Try Out uji kompetensi.

\section{Saran}

Dari hasil penelitian ini maka disarankan agar penggunaan Google Form untuk test di lokasi penelitian (Stikes Pamenang) tidak digunakan terlebih dahulu dan perlu dilakukan penelitian lebih lanjut tentang faktor lain yang berpengaruh terhadap penerimaan penggunaan Google Form sebagai metode test, sehingga dapat menjadi rekomendasi dan pertimbangan bagi penggunaan metode ini pada masa yang akan datang.

\section{UCAPAN TERIMA KASIH}

Terimakasih kepada Prodi Diploma III Keperawatan, Ketua LPPM serta Komite Etik Stikes Pamenang yang telah menjadi memberikan kesempatan kepada peneliti untuk melakukan penelitian ini.

\section{DAFTAR PUSTAKA}

Fauzi (2014) Penggunaan Google Form Sebagai Alat Evaluasi Pembelajaran Pada Mata Pelajaran Bahasa Indonesia : Studi Deskriptif Analitis pada Kelas VIII di Sekolah Menengah Pertama Negeri 1 Lembang.Jan.

Ghofar, Abdul (2016), Pengembangan Kompetensi Bagi Pendidikan D-III Keperawatan, Makalah, disampaikan pada pelatihan Item Development, Item Review dan Item Banking Administration, 2015

Hartina, Ayu; Tahir, Takdir; Nurdin, Nurhaya ; Djafar , Mudawati (2017), Faktor yang Berhubungan dengan Kelulusan Uji Kompetensi Ners Indonesia (UKNI) di Regional Sulawesi, JURNAL PERSATUAN PERAWAT NASIONAL INDONESIA ( JPPNI ) Volume 2, Nomor 2, AgustusNovember 2017

Iriana, Paramita (2015), Gambaran Umum Pelaksanaan Uji Kompetensi di Indonesia, Makalah, disampaikan pada pelatihan Pengawas Pusat, 9-10 September 2014

Iriana, Paramita (2019), Gambaran Umum Pelaksanaan Uji Kompetensi di Indonesia, Makalah, disampaikan pada pelatihan Pengawas Pusat, 10 Sep Oktober 2019

Kim , Dong-gook ; Park, Chongwoo (2012). Gender differences in the effectiveness of Google Forms in class. Journal of Instructional Pedagogies

KopertisV (2014) Pemetaan Kualitas Perguruan Tinggi Kesehatan berdasarkan hasil Uji Kompetensi Tenaga Kesehatah, Warta Kopertis V, edisi XIX, Juni 2014

M. Iqbal, R. Rosramadhana, B. K. Amal, and M. E. Rumapea (2018). Penggunaan Google Forms Sebagai Media Pemberian Tugas Mata 
Kuliah Pengantar Ilmu Sosial. JUPIIS J. Pendidik Ilmu-ilmu Sos., vol. 10, no. 1, pp. 120-127, 2018.

M. Khairudin, F. Wulandari, D Mardapi (2020) Implementation of Computer Bases Assessment on Students' Aptitude Using Online and Multimedia Test for Talent Mapping, Journal of Physics: Conference Series, 1456012059

Masfuri (2016).Uji Kompetensi Perawat Di Indonesia. JPPNI Vol.01/No.01/AprilJuli/2016

Meinawati, Tristy; Satoto, Kodrat Iman ; Nurhayati , Oky Dwi.(2013). Perancangan Aplikasi Ujian Online Jurusan Sistem Komputer Universitas Diponegoro. Jurnal Teknologi dan Sistem Komputer, Vol. 1 no 4 pp.169-178 Oct.2013

Muwanga-Zake, J.W.F. (2006). Applications of computer-aided assessment in the diagnosis of science learning and teaching, Education Journal of Education and Development Using ICT, Vol 2, Number 4

Prawoto, Edy (2016), Peran Strategis AIPViKI dalam Mengkawal Kualitas Pendidikan Program Studi D-III Keperawatan, Makalah, disampaikan pada Workshop Pengembangan Kurikulum Diploma III Keperawatan Jawa Timur, Surabaya, 14-15 Juni 2014

Rakib U. Rayhan, et.al.(2013) Administer and collect medical questionnaires with Google documents: a simple, safe, and free system Appl Med Inform. 2013 ; 33(3): 12-21.

Syah, D.Z.R. (2017). Hubungan Prestasi Akademik dan Faktor Eksternal dengan Kelulusan Uji Kompetensi Mahasiswa Keperawatan Stikes Jenderal Achmad Yani Yogyakarta, Jurnal Keperawatan Muhammadiyah

U. Rahardja, N. Lutfiani, \& M. S. Alpansuri (2018). Pemanfaatan Google Formulir Sebagai Sistem Pendaftaran Anggota Pada Website Aptisi.or.id. SISFOTENIKA, vol. 8, no. 2, pp. 128-139, Jul.2018

Vasantha Raju N., \& Harinarayana, N.S. (2016, January). Online survey tools: A case study of Google Forms. Paper presented at the National Conference on "Scientific, Computational \& Information Research Trends in Engineering, GSSS-IETW, Mysore.

WHO-SEARO (2003). Nursing and Midwifery Workforce Management: Conceptual Framework. New Delhi: SEARO Publication.

Williams, Brett. 2007. Students' perceptions of prehospital web-based examinations. Education, Journal of Education and Development Using ICT Vol 3, Number 1
Yitno. 2019. Tantangan dan Tren Pendidikan Diploma III Keperawatan. Article pada Pelatihan Item Development, Item Review Soal Uji Kompetensi Diploma Keperawatan, Surabaya : 25-26 April 2019

Ghofar, Abdul. 2019. Teknik Pengembangan Soal Uji Kompetensi. Article pada Pelatihan Item Development, Item Review Soal Uji Kompetensi Diploma Keperawatan, Surabaya : 25-26 April 2019 